\title{
EFEKTIVITAS PENGELOLAAN ANGGARAN ALOKASI DANA DESA TERHADAP PEMBANGUNAN DAERAH DAN OTONOMI DAERAH DI DESA MADUMULYOREJO KECAMATAN DUKUN KABUPATEN GRESIK
}

\author{
Sholihatul Fitri \\ UIN Sunan Ampel Surabaya | Sholihafitri97@gmail.com
}

\begin{abstract}
Abstrak: Pengelolaan Alokasi Dana Desa terdiri dari empat (4) tahap, yaitu penerimaan, perencanaan, pelaksanaan dan pertanggungjawaban. Berdasarkan hasil penelitian tahapan penerimaan Alokasi Dana Desa sudah efektif karena mencakup azas adil dan azas merata. Tahapan perencanaan sudah efektif karena sudah melaksanakan kegiatan musrenbangdes dengan program kerja yang terlaksana atas adanya anggaran Alokasi Dana Desa sebesar 83\% dikarenakan salah satu program yang sudah masuk dalam musrenbangdes dengan anggaran Alokasi Dana Desa 2018 tidak cukup dan diambilkan dari dana SILPA tahun kemarin. Pada tahapan pelaksanaan atas program kerja berupa pembangunan fisik dan non fisik sudah terealisasikan anggaran dari Alokasi Dana Desa sebesar 83\%. Tahapan pertanggungjawaban berdasarkan hasil penelitian sudah efektif dengan adanya Surat Pertanggungjawaban dan sudah tersampaikan kepada inspektorat dengan tepat waktu serta sudah terlaksananya publikasi kepada masyarakat dalam bentuk papan pengumuman. Pemerintah Desa Madumulyorejo agar selalu melibatkan masyarakat dalam melaksanakan kegiatan desa, karena dengan keterlibatan masyarakat maka akan menciptakan pemerintahan desa yang transaparan. Serta selalu memperbaiki sistem kepemerintahan yang baik dan jujur. Metodelogi penelitian yang digunakan adalah pendekatan kualitatif deskriptif dengan jenis penelitian studi kasus. Pengumpulan data dilakukan dengan wawancara dengan informan dalam penelitian ini yaitu kepala desa, sekretaris desa, kepala urusan keuangan desa, tokoh masyarakat dan masyarakat.
\end{abstract}

Keywords: efektivitas; alokasi dana desa; pembangunan daerah, otonomi daerah 


\section{Pendahuluan}

Setiap negara berambisi besar untuk memiliki pembangunan nasional yang baik dan sejahtera. Pada masa Pemeirntahan Joko Widodo - Jusuf Kalla dalam mendukung pembangunan nasional dengan menerapkan kebijakan yang bertajuk Nawacita. Program prioritas pembangunan nasional yang bertajuk Nawacita tersebut merupakan rangkaian dari sembilan program prioritas Joko Widodo - Jusuf Kalla yang sudah tertuliskan pada dokumen Visi, Misi dan program kerja kepemerintahan Joko Widodo - Jusuf Kalla. Dalam isi poin nomor 3 Nawacita ini yang menyatakan "Kami akan membangun Indonesia dari pinggiran dengan memperkuat daerah-daerah dan desa dalam kerangka negara kesatuan" yang sudah terealisasikan sejak awal tahun 2018 sudah ada Program Padat karya Tunai untuk pedesaan. Sebagai permulaan, target dalam program ini adalah 1.000 desa dari 100 kabupaten yang memiliki permasalahan ketimpangan sosial yang tinggi. Anggaran program ini diambil dari Dana Desa. Pada tahun 2018, anggaran Padat Karya Tunai mencapai Rp.18 triliun untuk seluruh desa yang ada di Indonesia. ${ }^{1}$

Dan saat ini pemerintah Indonesia terus meningkatkan pembangunan nasional baik itu dari segi fisik maupun non fisik dengan menyelaraskan laju pembangunan daerah. Pembangunan daerah memiliki pengaruh yang besar terhadap peningkatan mutu pembangunan nasional karena didalamnya terdapat upaya untuk meningkatkan taraf kesejahteraan masyarakat dengan melakukan pemerataan pembangunan dan hasil-hasilnya yang menyeluruh secara langsung pada kepentingan sebagian besar masyarakat yang bermukim di pedesaan. ${ }^{2}$

\section{Kerangka Teoritis \\ Alokasi Dana Desa}

\footnotetext{
1 “Nawacita, 4 Tahun Jokowi-JK dan Realisasi," Sabtu, 20 Oktober 2018, diakses Mei 12, 2019, https://m.detik.com/news/berita/d-4265140/4-tahun-jokowi-jk-danrealisasi-nawacita.

2 Suwondo Chandra Kusuma Putra, Ratih Nur Pratiwi, "Pengelolaan Alokasi Dana Desa Dalam Pemberdayaan Masyarakat (Studi pada Desa Wonorejo Kecamatan Singosari Kabupaten Malang)" 1, no. 6 (2012): 1203-1212.
} 
Alokasi Dana Desa merupakan dana yang bersumber dari dana perimbangan keuangan pusat dan daerah yang diperuntukkan untuk desa dari Kabupaten/Kota yang sudah dituangkan dalam APBDes (Anggaran Pendapatan Belanja Desa). Dengan adanya pemberian Alokasi Dana Desa diharapkan mampu memenuhi kebutuhan desa dalam melaksanakan otonomi supaya desa dapat berkembang serta mampu meningkatkan pembangunan dan pertumbuhan pada wilayah yang strategis. Adapun besaran Alokasi Dana Desa yang diterima oleh desa yaitu 10\% (sepuluh persen) dari Dana Alokasi Umum dan Dana Bagi Hasil yang bersumber dari dana perimbangan keuangan pusat dan daerah yang diterima oleh Kabupaten/Kota dalam Anggaran Pendapatan dan Belanja Desa. ${ }^{3}$

Secara umum, mengenai pengelolaan Alokasi Dana Desa ataupun kebijakan yang telah dikeluarkan oleh suatu dinas ataupun instansi dapat disimpulkan bahwa pengelolaan Alokasi Dana Desa masih kurang membuka ruang dengan masyarakat untuk dapat terlibat dalam pengelolaan Alokasi Dana Desa yang dimulai dari tahap perencanaan, pelaksanaan maupun pengawawan, berikut penjelasannya;

\section{Tahap Perencanaan}

Perencanaan pada keuangan desa berasal dari hasil kesepakatan dalam musyawarah desa yang menjadi dokumen terdiri dari RPJMD dan Rencana kerja Pemerintah Desa (RKPD) dengan berpedoman pada perencanaan pembangunan desa. Dalam forum musyawarah perencanaan pembangunan desa (Musrenbangdes) dengan melibatkan Badan Permusyawaratan Desa (BPD) dan seluruh lapisan masyarakat desa yang kemudian menghasilkan susunan Rencana Pembangunan Jangka Menengah Daerah (RPJMD) dan Rencana Kerja Pemerintah Desa (RKPD). Penetapan RPJMD paling lama tiga bulan terhitung semenjak kepala desa dilantik. RPJM tersebut berisikan mengenai visi misi kepala desa yang sudah terpilih, rencana pelaksanaan pemerintahan desa, pelaksanaan pembangunan, pemberdayaan masyarakat dan arah pada kebijakan perencanaan pembangunan desa.

Dimana dalam penyusanan rancangan APBDes harus disusun

\footnotetext{
${ }^{3}$ Desy Purnamasari, “Analisis Pengelolaan Alokasi Dana Desa (ADD) di Kecamatan Jabon Kabupaten Sidoarjo 2015" (Universitas Jember, 2016).
} 
oleh pemerintah desa. Penyusunan rancangan APBDes dilakukan setelah adanya penetapan peraturan bupati/kota mengenai tata cara pembagian dan penetapan rincian Alokasi Dana Desa. Peenetapan peraturan bupati/kota wajib di sampaikan dan disosialisasikan kepada desa untuk mengetahui besaran Alokasi Dana Desa untuk masing-masing desa.

Dalam menyusun pembiayaan kegiatan-kegiatannya kepala desa harus berpedoman pada Rencana Kerja Pemerintah Desa (RKPD). Pembagian Alokasi Dana Desa tersebut digunakan untuk membiayai kegiatan- kegiatan yang sesuai dengan daftar urutan kegiatan yang telah ditetapkan dalam RKPD. Kepala desa tidak diperbolehkan merubah daftar kegiatan yang sudah direncanakan dan telah dibiayai Alokasi Dana Desa yang sudah ditetapkan dalam RKPD.

\section{Tahap Pelaksanaan}

Pelaksanaan merupakan suatu bentuk tindakan atau pelaksanaan dari sebuah rencana yang telah disusun secara baik dan terperinci yang kemudian diimplemesntasikan atau bisa disebut juga sebagai penerapan. Berdasarkan pada peraturan pemerintah No. 60 Tahun 2014 tentang Dana Desa yang bersumber dari dana APBN dan Undang-Undang Nomor 43 Tahun 2014 tentang Desa yang telah mengatur beberapa pokok mengenai pokok penggunaan keuangan desa.

Pelaksanaan Alokasi Dana Desa yang sudah ditetapkan muncul sebelum adanya transaksi penerimaan dan pengeluaran keperluan desa yang dilaksanakan melalui rekening kas desa. Dengan adanya dukungan bukti yang lengkap dan sah maka semua penerimaan dan pengeluran desa dapat dipertanggungjawabkan oleh desa. Jadi, setelah adanya pelaksanaan perencanaan maka langkah selanjutnya yaitu pengorganisasian mengenai pelaksanaan dari kegiatan tersebut agar semua berjalan sesuai dengan keinginan.

\section{Tahap Pertanggungjawaban}

Berdasarkan Peraturan Daerah Nomor 18 Tahun 2006 tentang Alokasi Dana Desa pasal 11 ayat 1 disebutkan, bahwa pembangunan pada skala desa yang anggarannya bersumber dari Alokasi Dana Desa dilaksanakan secara swakelola oleh Lembaga Pemberdayaan Masyarakat Desa (LPMD) dan dipertanggungjawabkan secara langsung kepada masyarakat dan 
Badan Permusyawaratan Desa (BPD). Sedangkan pada Peraturan Pemerintah Nomor 43 Tahun 2014 yang telah diubah dengan Peraturan Pemerintah Nomor 47 Tahun 2014 tentang Peraturan Pelaksanaan Undnag-Undang Nomor 6 Tahun 2014 tentang desa, selain pada penyampaian laporan realisasi pelaksanaan APBDesa atau Alokasi Dana Desa.

Dalam halnya melaksanakan tugas, kewenangan, hak, dan kewajibannya dalam pengelolaan keuangan desa, diwajibkan untuk kepala desa untuk menyampaikan laporan keuangan desa. Bentuk laporan tersebut bersifat periodik semesteran dan tahunan yang disampaikan ke Bupati/Walikota dan Badan Permusyawaratan Desa. Bentuk laporan kepada Bupati/Walikota dengan melalui camat yang berisikan laporan semesteran realisasi pelaksanaan APBDesa, Laporan pertanggungjawaban realisasi pelaksanaan APBDesa kepada Bupati/Walikota setiap akhir tahun anggaran, dan laporan realisasi penggunaan dana desa. Sedangkan bentuk laporan kepada Badan Permusyawaratan Desa berisikan mengenai laporan keterangan pertanggungjawaban realisasi pelaksanaan APBDesa yang terdiri dari pendapatan, belanja, dan pembiayaan. ${ }^{4}$

\section{Pembangunan Daerah}

Pada prinsipnya pembangunan merupakan salah satu upaya dalam memanfaatkan Sumber Daya guna membangun masyarakat secara menyeluruh untuk kesejahteraan rakyat dengan dilakukan secara terencana dan berkelanjutan.

Pembangunan nasional dan pembangunan daerah memiliki arti dan peranan penting dalam mencapai tujuan nasional, karena desa masih memiliki struktur lembaga yang kuat karena masih kental dengan hukum adat desa dan sangat menjaga keutuhannya. Menurut Suparno, pembangunan desa merupakan pembangunan yang dilakukan dengan imbang antara pemerintah dengan masyarakat. Dimana kewajiban pemerintah dalam halnya pembangunan menyediakan sarana dan prasarana, selebihnya diarahkan dengan kemampuan masyarakat itu sendiri. Adapun mekanisme dalam pembangunan desa adalah

\footnotetext{
${ }^{4}$ Badan Pengawas Keuangan dan Pembangunan, “Petunjuk Pelaksanaan Bimbingan \& Konsultasi Pengelolaan Keuangan Desa" (2015).
} 
dengan memadukan antara kegiatan partisipasi masyarakat dalam pihak dan kegiatan pemerintah di satu pihak. Hakikatnya pembangunan desa dilakukan oleh masyarakat sendiri, sedangkan pemerintah memberikan bimbingan, bantuan, pembinaan dan pengawasan.

Oleh karena itu, dalam halnya pelaksanaan pembangunan desa diperlukan adanya koordinasi antara pemerintah pusat dengan daerah serta desa sebagai tempat pelaksanaan pembangunan agar saling menunjang dan terlaksana sesuai dengan yang diharapkan dari keseluruhan program kegiatan tersebut, sehingga dapat berdaya guna dan berhasil guna. Akan tetapi, ada juga permasalahan dalam pembangunan di pedesaan yaitu minimnya aset yang dikuasi oleh masyarakat dan kurangnya akses masyarakat pedesaan pada sumber daya ekonomi, rendahnya tingkat pelayanan prasarana dan sarana pedesaan dan rendahnya kualitas Sumber Daya Manusia di desa yang mayoritas masyarakatnya memiliki keterampilan rendah, lemahnya kelembagaan dan organisasi berbasis masyarakat, lemahnya koordinasi lintas bidang dalam pengembangan kawasan pedesaan.

\section{Otonomi Daerah}

Pada hakikatnya kata otonomi menyangkut pada dua hal pokok yaitu, kewenangan dalam membuat hukum sendiri (Own Laws) dan kebebasan dalam mengatur urusan pemerintahannya sendiri (Self Goverment). Maka otonomi daerah itu diartikan sebagai suatu hak atau wewenang dalam mengurus pemerintahannya sendiri bagi suatu daerah otonom. Adapun hak dan wewenang tersebut yaitu mengenai pengaturan pemerintahan dan pengelolaan pembangunan yang sudah di alihkan oleh pemerintah pusat kepada pemerintah daerah.

Dasar hukum dalam Otonomi Daerah Undang-Undang Republik Indonesia Nomor 32 Tahun 2004 tentang pemerintahan daerah bahwasanya otonomi daerah adalah hak, wewenang dan kewajiban daerah otonom dalam mengatur dan mengurus kepentingan pemerintahannya sendiri dan kepentingan masyarakat berdasarkan peraturan yang sudah ditetapkan. Daerah yang disebut sebagai daerah merupakan suatu kesatuan masyarakat yang memiliki batas-batas wilayah dengan memiliki 
kewenangan dalam mengatur dan mengurus kepentingan pemerintahan dan masyarakat berdasarkan aspirasi masyarakat sekitar dengan menganut sistem Negara Kesatuan Republik Indonesia. ${ }^{5}$

\section{Metodologi Penelitian}

Penelitian ini dilakukan dengan menggunakan metode kualitatif dengan pendekatan studi kasus. Penelitian dengan menggunakan studi kasus yaitu memperhatikan semua aspek yang penting dari suatu kasus yang akan diteliti dengan tipe penelitian studi kasus dapat mempermudah peneliti dalam menyampaikan suatu gambaran secara lebih detail mengenai suatu situasi atau objek.

Lokasi penelitian yang dilakukan oleh peneliti di Desa Madumulyorejo Kecamatan Dukun Kabupaten Gresik. Adapun alasan penetapan lokasi penelitian ini karena Desa Madumulyorejo Kecamatan Dukun Kabupaten Gresik masih tergolong desa yang terpinggir.

Teknik analisis data yang digunakan pada penelitian ini adalah Teknik validasi data yang digunakan peneiti adalah derajat kepercayaan (Credibiliy) dengan menggunakan triangulasi. Menurut Patton, triangulasi merupakan teknik pemeriksaan keabsahan data yang dilakukan memanfaatkan sesuatu yang lain. Maksud dari memanfaatkan sesuatu yang lain yaitu dengan memanfaatkan penggunaan sumber, metode dan teori.

\section{Hasil dan Pembahasan}

\section{A. Analisis Efektifitas Pengelolaan Alokasi Dana Desa di Desa Madumulyorejo Kecamatan Dukun Kabupaten Gresik}

Pengelolaan anggaran Alokasi Dana Desa di Desa Madumulyorejo Kecamatan Dukun Kabupaten Gresik terdapat empat (4) tahap, antara lain:

\section{Tahap penerimaan}

Pemberian anggaran Alokasi Dana Desa diberikan berdasarkan keadaan geografis, jumlah penduduk dan

${ }^{5}$ HAW Widjaja, Otonomi Daerah dan Daerah Otonom, Edisi 1. (Jakarta : PT Raja Grafindo Persada, 2002). 
kebutuhan pada desa tersebut. Desa Madumulyorejo yang merupakan salah satu desa yang ada di Kecamatan Dukun Kabupaten Gresik yang mendapatkan jumlah anggaran Alokasi Dana Desa yang cukup besar. Adapun total dari penerimaan anggaran Alokasi Dana Desa yang diterima oleh Desa Madumulyorejo pada tahun 2018 sebesar Rp. 302.645 .000 yang $42,40 \%$ dari keuangan desa. Dengan adanya anggaran Alokasi Dana Desa ini dapat membantu kinerja pemerintahan desa Madumulyorejo dalam meningkatkan kesejahteraan masyarakat desa.

Dimana dalam jumlah anggaran Alokasi Dana Desa yang sudah diterima oleh Desa Madumulyorejo sudah 100\% sesuai dengan rumus dalam penentuan besaran Alokasi Dana Desa yang didasarkan pada azas adi dan azas merata. Ada dua yang menentukan dalam penentuan besaran Alokasi Dana Desa yaitu, azas merata dan azas adil. Dimana dalam azas merata sebesar 60\% dari total Alokasi Dana Desa Kabupaten Gresik yang kemudian disebut dengan Alokasi Dana Desa Minimun. Sedangkan pada azas adil sebesar $40 \%$ dari total Alokasi Dana Desa Kabupaten Gresik yang kemudian disebut juga dengan Alokasi Dana Desa Proporsional.

\section{Tahap Perencanaan}

Pada tahap perencanaan pengelolaan Alokasi Dana Desa di pemerintahan Desa Madumulyorejo Kecamatan Dukun Kabupaten Gresik sudah sesuai dengan ketentuan yang berlaku. Tahap perencanaannya dimulai dengan pembentukan tim pelaksana dan proses perencanaannya dilaksanakan dengan forum musyawarah desa atau musrenbangdes. Tim dalam pelaksanaan Alokasi Dana Desa pada tahap ini terdiri dari Kepala Desa, Sekretaris desa, Kepala Urusan Keuangan Desa dan juga dibantu dengan lembaga kemasyarakatan desa.

Secara mekanisme dalam tahap perencanaan pengelolaan Alokasi Dana Desa sudah sesuai dengan alur dalam peraturan Daerah Kabupaten Gresik Nomor 10 Tahun 2009 tentang pengelolaan Alokasi Dana Desa. Akan tetapi, peran masyarakat dalam keikutsertaan tahap perencanaan pengelolaan Alokasi Dana Desa masih kurang dikarenakan minimnya pengetahuan yang dimiliki oleh masyarakat Desa Madumulyorejo mengenai perencanaan pengelolaan Alokasi Dana Desa. 


\section{Tahap pelaksanaan}

Pelaksanaan pengelolaan Alokasi Dana Desa di Desa Madumulyorejo didasarkan pada Peraturan Daerah Kabupaten Gresik Nomor 10 Tahun 2009 tentang pengelolaan Alokasi Dana Desa. Telah disebutkan bahwa belanja desa yang telah ditetapkan dalam APBDesa digunakan untuk belanja aparatur desa dan operasional pada pemerintah Desa dan Badan Permusayawarat Desa dengan ketentuan sebesar 30\% dan 70\% untuk belanja pemberdayaan masyarakat.

Berdasarkan pada ketentuan Peraturan Daerah Kabupaten Gresik Nomor 10 tahun 2009 tentang penetapan besaran Alokasi Dana Desa minimum dan Alokasi Dana Desa proporsional di wilayah pemerintah Kabupaten Gresik Kecamatan Dukun pada Tahun anggran 2018 besaran Alokasi Dana Desa yang diterima oleh Desa Madumulyorejo sebesar Rp. 302.645 .000 dan diimplementasikan dalam bentuk penyempurnaan pembangunan fisik dan non fisik.

Dalam perencanaan pengelolaan Alokasi Dana Desa di Desa Madumulyorejo dari segi administratif sudah sesuai dengan peraturan Daerah Kabupaten Gresik Nomor 10 Tahun 2009 tentang pengelolaan Alokasi Dana Desa dan berjalan sesuai dengan harapan pemerintah dan masyarakat desa. Namun, dalam halnya pasrtisipasi masyarakat sebagai tim evaluasi masih kurang karena masyarakat kurang memahami mengenai alur dan tahapan dalam pelaksanaan pengelolaan Alokasi Dana Desa.

\section{Tahap Pertanggungjawaban}

Pada tahap pertanggungjawaban pengelolaan Alokasi Dana Desa di Desa Madumulyorejo secara administrasi sudah sesuai dengan pedoman dan aturan yang berlaku dari tahun ke tahun karena laporan disusun langsung oleh Kepala Urusan Keuangan selanjutnya dikumpulkan ke Pemerintahan Desa untuk diverifikasi dan diserahkan kepada Inspektorat Kabupaten untuk diperiksa serta selalu tepat waktu dalam pelaporannya.

Tahap pertanggungjawaban pengelolaan Alokasi Dana Desa Madumulyorejo sudah baik dari segi administratif dan sudah sesuai dengan Peraturan Daerah Kabupaten Gresik Nomor 10 Tahun 2009 tentang Pengelolaan Alokasi Dana Desa. Dimana dalam laporan pertanggungjawaban tersebut sudah dibuat secara 
per periodik dan tahunan serta sudah tersampaikan surat pertanggungjawabannya kepada Bupati/Walikota dan Badan Permusyawaratan Desa (BPD) dengan tepat waktu. Pada tahap publikasi dengan masyarakat juga tersampaikan dengan baik dalam bentuk tulisan yang berupa pamflet atau papan pengumuman mengenai rincian penerimaan dan pengeluaran anggaran Alokasi Dana Desa. Akan tetapi, keikutsertaan masyarakat sebagai tim evaluasi masih karena minimnya kefahaman mengenai tahap pertanggungjawaban pengelolaan Alokasi Dana Desa.

\section{B. Analisis Dampak Pengelolaan Alokasi Dana Desa terhadap Kualitas Pembangunan Daerah dan Otonomi Daerah di Desa Madumulyorejo Kecamatan Dukun Kabupaten Gresik}

1. Analisis Pengelolaan Alokasi Dana Desa dalam Meningkatkan Pembangunan Fisik dan Otonomi Daerah

Pengelolaan Alokasi Dana Desa terhadap pembangunan fisik di Desa Madumulyorejo sudah sesuai dengan apa yang diharapkan oleh masyarakat. Dari sekian banyak wujud nyata pembangunan fisik yang mendapatkan respon paling banyak dari masyarakat yaitu dalam bidang irigasi karena mayoritas masyarakat Desa Madumulyorejo memiliki mata pencaharian sebagai petani. Dalam pembangunan segi fisik di Desa Madumulyorejo sudah mampu menerapkan Misi yang ada di Desa Madumulyorejo dengan mengikutsertakan masyarakat dalam proses perencanaan pengambilan keputusan dan pelaksanaan pembangunan serta meningkatkan pembangunan ekonomi desa yang berbasis ekonomi kerakyatan. Namun, peran masyarakat sebagai Tim evaluasi pembangunan masih kurang karena masyarakat lebih mementingkan pada kepentingan pribadi. Jadi, pada pembangunan fisik di Desa Madumulyorejo ini dinilai sudah efektif karena mampu menerapkan Otonomi daerah sebagai pemenuhan atas hak dan kewajiban tugas sebagai Pemerintahan Desa dan dibuktikan dengan dapat mewujudkan kebutuhan desa.

2. Analisis Dampak Pengelolaan Alokasi Dana Desa dalam Meningkatkan Pembangunan Non Fisik dan Otonomi Daerah. 
Pengelolaan Alokasi Dana Desa dalam meningkatkan pembangunan non fisik di Desa Madumulyorejo sudah sesuai dengan apa yang diharapkan oleh masyarakat yang telah disesuaikan dengan Visi dan Misi Desa Madumulyorejo. Akan tetapi, dalam melihat dukungan dan aspirasi masyarakat sebagai tim evaluasi masih kurang terlibat. Karena masyarakat lebih mementingkan kepentingan pribadinya dan menjadi tak acuh terhadap program yang dilaksanakan oleh pemerintah desa. Jadi, pada pembangunan non fisik yang ada di Desa Madumulyorejo dinilai sudah efektif dan mampu menerapkan Otonomi daerah sebagai pemenuhan atas hak dan wewenangnya sebagai pemerintahan Daerah karena mampu memenuhi dalam kekurangan dari kualitas masyarakat desa.

\section{Kesimpulan}

Efektivitas pengelolaan Alokasi Dana Desa di Desa Madumulyorejo Kecamatan Dukun Kabupaten Gresik terdapat empat tahap antara lain, tahap penerimaan, perencanaan, pelaksanaan dan pertanggungjawaban. Berdasarkan hasil penelitian dari empat tahap pengelolaan Alokasi Dana Desa secara administratif sudah sesuai dengan Peraturan Daerah Kabupaten Gresik Nomor 10 Tahun 2009 tentang Pengelolaan Alokasi Dana Desa. Akan tetapi, keikutsertaan masyarakat dalam pengelolaan Alokasi Dana Desa masih kurang karena minimnya pengetahuan yang difahami mengenai pengelolaan Alokasi Dana Desa yang akibatnya masyarakat menjadi tidak merespon kegiatan pengelolaan Alokasi Dana Desa.

Dampak pengelolaan Alokasi Dana Desa terhadap kualitas pembangunan daerah dan otonomi daerah di Desa Madumulyorejo Kecamatan Dukun Kabupaten Gresik sudah efektif karena sudah sesuai dengan harapan pemerintah dan masyarakat desa yang telah disesuaikan dengan Visi dan Misi Desa Madumulyorejo. Terwujudnya dari pembangunan fisik berupa pembangunan irigasi pertanian, pembangunan saluran drainase, pembangunan gapura desa, pembangunan lapangan bola voli, perbaikan jalan poros desa dan pemugaran makam 
desa. Bentuk wujud nyata dari pembangunan non fisik berupa pengadaan taman posyandu untuk lansia dan balita, dan pengadaan insentif guru Taman Pendidikan Al-Qur'an. Akan tetapi, keterlibatan masyarakat Madumulyorejo dalam memberikan aspirasi dan dukungannya sebagai tim evaluasi terhadap program Pemerintahan Desa masih kurang. Pemerintahan Desa Madumulyorejo sudah dianggap mampu menerapkan Otonomi Daerah di wilayahnya sebagai pemenuhan atas hak dan wewenangnya sebagai pemerintahan daerah yang mampu memenuhi kekurangan yang ada di desa dengan memanfaatkan anggaran Alokasi Dana Desa.

\section{Daftar Referensi}

Badan Pengawas Keuangan dan Pembangunan. "Petunjuk Pelaksanaan Bimbingan \& Konsultasi Pengelolaan Keuangan Desa" 2015.

Chandra Kusuma Putra, Ratih Nur Pratiwi, Suwondo. "Pengelolaan Alokasi Dana Desa Dalam Pemberdayaan Masyarakat (Studi pada Desa Wonorejo Kecamatan Singosari Kabupaten Malang)" 1, no. 6 (2012): 1203-1212.

Purnamasari, Desy. "Analisis Pengelolaan Alokasi Dana Desa (ADD) di Kecamatan Jabon Kabupaten Sidoarjo 2015." Universitas Jember, 2016.

Widjaja, HAW. Otonomi Daerah dan Daerah Otonom. Edisi 1. Jakarta: PT Raja Grafindo Persada, 2002.

"Nawacita, 4 Tahun Jokowi-JK dan Realisasi." Sabtu, 20 Oktober 2018. Diakses Mei 12, 2019. https://m.detik.com/news/berita/d-4265140/4-tahunjokowi-jk-dan-realisasi-nawacita. 
Volume 4, No. 1, Des 2019| 69 